\title{
A Preliminary Survey of Hermeneutical Principles Found within the Bahá'í Writings
}

\author{
Dann J. May
}

\begin{abstract}
One of the unique features of the Bahá'í Faith is its explicit references to hermeneutical principles. These principles are used by the central figures of the Bahá'í' Faith to interpret not only the religious writings of other traditions but its own writings as well. While such authoritative interpretations make up an integral part of the Bahá'í' canon, they do not necessarily contradict or even limit the vital role which individual interpretation plays. The main focus of this paper is a discussion of eight interpretive principles found within the Bahá'í writings. This paper will examine: the multiple meanings contained within religious texts; the symbolic and mythological nature of religious language which distinguishes it from philosophical, historical, or scientific accounts; the role of science and reason in the formulation of interpretations made from religious sources; the progressive and relative nature of religious truth; the essential and nonessential aspects of every religious tradition; the problem of personal biases and presuppositions; the independent investigation of truth; and the need for interpretive moderation. The final section of this paper briefly examines how several of these interpretive principles function interdependently in the Bahá'í' exegesis of a prophetic passage from the Book of Isaiah.

\section{Résumé}

Un des aspects particuliers de la Foi bahá'íe est sa référence explicite aux principes herméneutiques. Ces principes sont employés par les figures centrales de la Foi bahá'íe pour interpreter non seulement les textes religieux d'autres traditions mais également ses propres écrits. Bien que ces interprétations autorisées fassent partie integrante des ecrits bahá'ís, elles ne contredisent ni ne limitent necessairement le rôle vital joué par l'interprétation individuelle. Le but principal de cette étude est une discussion de huit principes interprétatifs que l'on retrouve dans les écrits bahá'ís. Les points suivants seront examines: les multiples significations contenues dans les textes religieux; la nature symbolique et mythologique du langage religieux qui le distingue du discours philosophique, historique ou scientifique; le rôle de la science et de la raison dans la formulation des interprétations faites à partir de sources religieuses; la nature progressive et relative de la vérité religieuse; les aspects essentiels et non essentiels de chaque tradition religieuse; le problème des préjugés personnels et des présuppositions; la recherche indépendante de la verité; et le besoin de modération dans l'interprétation. La dernière partie de cette étude examine brièvement comment plusieurs principes d'interprétation entrent en jeu dans l'exégèse bahá'íe d'un passage prophetique du livre d'Isaïe.
\end{abstract}

\section{Resumen}

Una caracteristica unica de la Fe Bahá'í es su referencia explícita de los principios hermeneuticos. Estos principios son usados por las figuras centrales de la Fe Bahá'í para interpretar no solamente las escrituras religiosas de otras religiones, sino que las suyas tambien. Mientras estas interpretaciones autoritarias forman parte integral de las leyes Bahá'í, no contradicen necesariamente o ponen limites al rol vital que la interpretación individual tiene. El enfoque principal de este ensayo es discutir ocho principios interpretativos hayados en las escrituras Bahá'í. Este ensayo examirá: las múltiples definiciones contenidas en textos religiosos; la naturaleza simbólica y mitológica del lenguaje religioso que lo distinqüe de los escritos filosóficos, históricos o científicos; el rol de la ciencia y el razonamiento en laformulación de interpretaciones hechas de fuentes religiosas; la naturaleza progresiva y relativa de la veracidad religiosa; los aspectos esenciales y no esenciales de toda tradición religiosa; el problema de los prejuicios y presuposiciones personales; la investigación independiente de la verdad; y la necesidad de tener moderación interpretativa. La sección final de este ensayo examina brevemente cómo varios principios interpretativos funcionan interdependientemente en la exégesis Bahá'í de un paisaje profético del libro de Isaías.

\section{Introduction}

Hermeneutics is broadly defined as the science and methodology of interpretation. It is primarily concerned with the overall interpretive process and the various theories and principles of interpretation, especially the 
principles of proper textual exegesis (Palmer, Hermeneutics 33). Thus, it is often distinguished from exegesis, which is commonly defined as the practical application of hermeneutical principles to the actual commentary of a text. The study of hermeneutics is increasingly recognized as fundamental to such disciplines as theology, religious studies, philosophy, literary criticism, and not surprisingly, psychology and psychiatry. ${ }^{1}$ However, the role of hermeneutics in the understanding of texts, especially those of a religious origin, remains the subject of an ongoing and often heated debate. This paper does not seek a solution to this debate but rather attempts to identify and discuss certain interpretive principles found within the Bahá'i writings. As the title implies, this paper is a preliminary but not an exhaustive survey of hermeneutical principles. The purpose of compiling these principles is twofold: to provide guidance to the individual Bahá' faced with the often bewildering task of understanding and interpreting passages from various religious texts, including the Bahá'í writings; and to present these principles to the scholarly community for comment, examination, and critical analysis. I have divided this discussion into three main topics:

- The role of authoritative interpretation and its relationship to individual interpretation;

- An examination of eight interpretive principles found within the Bahá'i writ ings—-the main concern of this paper; and

- A brief examination of Bahá’í exegesis.

\section{Authoritative versus Individual Interpretation}

Authoritative interpretations made by the central figures of the Bahá'i Faith—the Báb, Baháu'lláh, 'Abdu'l-Bahá, and Shoghi Effendi-comprise an important and integral part of the Bahá'í canon. ${ }^{2}$ Their interpretations can be grouped into two broad types: those which explain, elaborate, clarify, or provide an overall summary or distillation of the Bahá'í writings; and those which explain and interpret past religious traditions and sacred writings. Bahá'í doctrine holds that both types of interpretation are infallible and divinely inspired. Although the Bahá'í concept of infallibility is certainly a vital issue, it is also a potentially enigmatic one and is clearly beyond the scope of this discussion. It might be argued that the very existence of infallible interpretation within the Bahá'i Faith precludes or, at the very least, severely limits the sphere of individual interpretation. According to Shoghi Effendi, such is not the case, provided that such interpretations are represented as "personal observations and reflections" (Unfolding 423). Hence, the existence of authoritative and infallible interpretation does not necessarily contradict or even restrict the freedom of individual interpretation or expression. Indeed, as we shall soon discover, the Baháí writ ings encourage and even instruct its adherents to make "interpretation[s] of the traditions" and to "expound the inner meanings of the Holy Books" (Baháu'ulláh, The Kitáb-i-Íqán 32-33 and 'Abdu'l-Bahá, Selections 275).

The Universal House of Justice wrote that "individual interpretation is considered the fruit of man's rational power and [is] conducive to a better understanding of the teachings" (Wellspring 88). In the Bahá'i writings and the recorded utterances of 'Abdu'l-Bahá, we are instructed in the art and science of interpretation and are asked to reflect upon, expound, discover, and interpret the symbolic and hidden meaning of religious texts. We are even assured that prayers have been said to aid our power of understanding. For example, Baháu'lláh concludes his discussion of the symbolic term oppression (tribulation) ${ }^{3}$ in The Kitáb-i-Íqán with these words: "Thus We instruct thee in the interpretation of the traditions, and reveal unto thee the mysteries of divine wisdom, that haply thou mayest comprehend the meaning thereof..." (32). After shedding light on the symbolic account of Adam and Eve in the Book of Genesis, "Abdu'l-Bahá states: "This is one of the meanings of the biblical story of Adam. Reflect until you discover the others" (Some Answered Questions 126). Elsewhere, "Abdu'l-Bahá wrote that it is his hope that the Bahá's will be so filled with the Holy Spirit that they will "disclose the mysteries, and set forth and expound the inner meanings of the Holy Books..." (Selections 275). Addressing a Bible study class in New York in 1912, "Abdu'l-Bahá told those in attendance: "I, therefore, pray in your behalf that you may be given the power of understanding these inner real meanings of the Holy Scriptures and may become informed of the mysteries deposited in the words of the Bible..." (Promulgation 460). And lastly, "Abdu'-Bahá wrote in one of his letters that Baháu'lláh gave him a most emphatic promise that eventually individuals filled with divine inspiration would arise to "interpret every hidden meaning" (Selections 251). It is clear from this brief sampling of Bahá'í texts that individual interpretation plays a vital and important role in the understanding of religious writings and traditions.

Nevertheless, the Bahá'í writings also recognize that our interpretations con tinually change over time as we gain a more complete understanding of a particular text, and while these interpretations may be enlightening, they can also be misleading or shortsighted. ${ }^{4}$ In other words, our interpretations are always subject to correction, modification, and revision. Furthermore, these interpretations influence not only how we perceive a particular text but also how we think and act in the world. In turn, our thoughts and actions are influenced by the world. This process does not stop here; the text may be reinterpreted with all the new insights and knowledge that we have gained from the world and so on ad infinitum. This back-and-forth process has been described as the "hermeneutic circle," although as Robert McAfee Brown points out, it is more aptly designated by the dynamic phrase "hermeneutical circulation" (Brown, Theology 86-88). Thus, while we are cautioned 
about the limitations of individual interpretation, we are certainly encouraged to make interpretations of religious texts (including the Bahá'í writings) and by implication, to interpret the rituals, doctrines, and worldviews associated with the various religious traditions.

\section{Principles of Interpretation}

Before discussing the interpretive principles found within the Bahá'í writings, I would like to make a few general comments about the nature of interpretation. First, it is impossible to understand or even speak about any statement, whether oral or written, whether ancient or modem, or whether primarily literal or symbolic in meaning, without interpretation. Words exist because of meaning, and their meaning is discovered and understood through interpretation. Furthermore, we live in a world of interpretation where everything that reaches us through our senses is interpreted by our brain. Moreover, as Richard Palmer writes: 'interpretation is ... perhaps the most basic act of human thinking; existing, itself may be said to be a constant process of interpretation" ( Hermeneutics 8-9).

However, there are four common pitfalls of which we must be aware before we can make interpretations. The first is the tendency to overconceptualize or overanalyze a text or religious tradition; it should be allowed to "speak" for itself (9). The second pitfall has to do with the meaning of words. There may be, on the one hand, a tendency to ignore the obvious meaning of the words, or on the other hand, to make unwarranted and extremely allegorical interpretations. The third pitfall is either to neglect or overemphasize the social and historical context of a particular tradition. The final pitfall is the tendency to interpret passages, especially obscure ones, out of context or in isolation from the larger body of canonical writings. The stage has now been set to examine in detail the hermeneutical principles found within the Baháí Faith.

\section{Religious Texts Contain Multiple Meanings}

The first interpretive principle is that the words of religious texts contain multiple meanings. Since we have established that the Bahá'í writings encour age the individual to make interpretations and to discover other meanings within a sacred text, it follows that the words of these texts-whether understood alone or taken as a body in complete narratives-must contain a variety of meanings. Indeed, Baháu'lláh states that the meaning of "the Word of God... can never be exhausted" ( Gleanings 175). Furthermore, near the end of The Kitáb-i-Íqán, He refers the reader to the following tradition (hadíth) of Islam: 'We speak one word, and by it we intend one and seventy meanings...'(255). In fact, the whole of The Kitáb-i-Íqán bears witness to this theme. For example, Bahá'u'lláh con cludes his discussion of the symbolic term heaven with these words: 'In the utterances of the divine Luminaries the term 'heaven' hath been applied to many and divers things.... In every instance, He hath given the term 'heaven' a special meaning... “(68). This example is typical of Bahá'u'lláh's hermeneutical approach to the numerous religious symbols and quotations from the Bible and the Qur'an which He examines in The Kitáb-i-Íqán. Obviously, we cannot confine ourselves to only one interpretation of a particular religious passage, nor even to one type or style of interpretation. We must consider a whole range of interpretations from the obvious and literal to the profoundly symbolic, from the historical context to the present-day application, and from the empirical and logical to the highly mystical and metaphysical, For similar reasons, we must not "view with too critical an eye" the sayings and writings made by others whether Baháí or not (Baháu'lláh, Gleanings 329). One could argue that certain interpretations are more probable than others, but this does not rule out the validity and usefulness of making all possible interpretations which are warranted by the text. It is for this reason, that even when an authoritative Bahá'i interpretation exists for a particular passage, this by itself, does not exclude the potential for other meaningful interpretations.

\section{The Symbolic and Mythological Character of Religious Language}

The second principle of interpretation is that religious texts are often purposely written in ambiguous, veiled, and symbolic language. Baháu'lláh writes in The Kitáb-i-Íqán that the founders of the world's religions speak a twofold language. The first language is clear and unambiguous, while the second is "veiled and concealed" and filled with "symbolic terms and abstruse allu sions." Examples of the first type of language include the laws and ordinances, the counsels and exhortations, and the teachings and principles found within each religion. Examples of the second type of language include the symbolic, mythological, mystical, prophetic, apocalyptic, and eschatological passages found in most, if not all, religious texts and traditions. In such cases where the veiled language can be identified (see the discussion on the role of science and reason in the interpretive process, p. 48), Bahá'u'lláh clearly states that: “...the literal meaning, as generally understood by the people, is not what hath been intended" (The Kitáb-i-Íqán 255). In addition, Baháu'lláh writes that the literal interpretation of the veiled and symbolic language is one of the primary reasons that persecution occurs in the formative age of every religion $(80-83,114)$.

Elsewhere in the writings and recorded utterances of 'Abdu'l-Bahá, the symbolic nature of religious language is also discussed. In his talks and lectures in America, 'Abdu'l-Bahá repeatedly admonished the Bahá'ís not to be satisfied with the outward or literal sense of religious language, and he encouraged them to 
understand the spiritual meanings contained within the words (Promulgation 459-60, 463, 245-46). During one of his talks in New Hampshire, 'Abdu'l-Bahá explained that: 'The Holy Books have their special terminolo gies which must be known and understood. Physicians have their own peculiar terms;... poets have their phrases; and scientists, their nomenclature." ${ }^{\prime 6}$ For these reasons, The Kitáb-i-Íqán discusses at some length and gives detailed and specific definitions for a number of common symbolic terms used within the Baháí Faith, Islam, Christianity, and Judaism, and to a lesser extent, the remaining religious traditions. ${ }^{7}$ In addition, definitions of these and other symbolic terms are scattered throughout the Bahá'í canon and the talks of 'Abdu'l-Bahá. Furthermore, a wide variety of religious myths, miracle narratives, rituals, and doctrines are also interpreted symbolically. ${ }^{8}$ In his essay entitled, The Reluctant Vision, T. Patrick Burke builds a convincing case that the primary function of religious language is the presentation of a vision of life, as opposed to the dissemination of historical and scientific facts. ${ }^{9}$ Therefore, where the use of veiled and symbolic language, as described by Bahá'ulláh, can be recognized, we must look beyond a strictly literal interpretation and discover the intended symbolic and allegorical meanings. We must "break the myth," in the words of the philosophical theologian Paul Tillich (1886-1965), by making conscious the symbolic character of mythological and symbolic language (Dynamics of Faith 50-52). Or, to the use the terminology of German theologian Rudolf Bultmann (1884-1976), we must' 'de-mythologize" religious language not by elim inating symbolic terms and mythic narratives from religious texts but by interpreting them (Jesus 18, 34-44).

But why is the meaning of religious language frequently veiled in symbolism and clothed in mythological narratives? Several reasons are given in the Bahá'í writings. First, symbolic language serves "to test and prove the peoples of the world," and to disclose "whatever lieth hidden in the heart of the malevolent" (Baháu'lláh, The Kitáb-i-Íqán 49, 255). Thus, symbolic language distinguishes true spiritual perception from narrow and exclusively literal understandings. Second, since the ignorant and illiterate masses are often unable to comprehend logical arguments, philosophical discourses, and theological debates, according to 'Abdu'l-Bahá, symbols and myths describing the rewards and punishments of the next life are used to uplift their ethical scope and moral behavior (Secret 84). Third, 'Abdu'l-Bahá writes that "hothing on earth can be demonstrated by words alone, and every level of existence is known by its signs and symbols..."(98-99). Finally, he explains that religious concepts "are too deep to be expressed by common words," therefore, these concepts are expressed in parable "in order to be understood and preserved for ages to come." 10 Tillich expresses a similar view in his book, Dynamics of Faith: "The language of faith is the language of symbols.... [Myths are] the combination of symbols of our ultimate concern.... For there is no substitute for the use of symbols and myths: they are the language of faith" (45, 50-51). In addition, literary critic William Righter observes that "what a myth does is to present a concrete possibility. To our openness in the face of ultimate questions to which we have no answers and for which explanations are simply not explanatory the myth poses another question: 'It's like this, isn't it?' And what follows is a story." 11

It should be obvious then, that religious language is primarily symbolic and mythological, that it is fundamentally different from the language found in philosophical treatises, scientific journals, historical documents, or legal dictates. Moreover, religious language has the potential to communicate profound understanding and convey powerful insights about ultimate questions that ordinary, scientific, or technical language often fails even to address, let alone satisfactorily answer.

\section{The Role of Science and Reason in the Interpretive Process}

Most people, especially those in the West, believe that scientific truth and the use of logic and reason are diametrically opposed to faith and religious knowledge. Commenting on this questionable but deeply entrenched dichotomy, the Research Department at the Bahá'i World Centre has stated:

It has become customary in the West to think of science and religion as occupying two distinct-and even opposed-areas of human thought and activity. This dichotomy can be characterized in the pairs of antitheses: faith and reason; value and fact. It is a dichotomy which is foreign to Bahá' thought and should be regarded with suspicion by Bahá'i scholars in every field. The principle of the harmony of science and religion means not only that religious teachings should be studied in the light of reason and evidence as well as of faith and inspiration, but also that everything in creation, all aspects of human life and knowledge, should be studied in the light of revelation as well as in that of purely rational investigation. ${ }^{12}$

Thus, the third interpretive principle rests on the important Bahá'i principle that 'religion must be in conformity with science and reason..."("Abdu'l-Bahá, Selections 299). By “religion," the Bahá'í writings mean reli gion shorn of its encrusting superstitions, imitations, dogmas, and obsolete laws. By "science," the Baháí writings mean the scientific method and the established theories, principles, and natural laws that are derived by that method.

During 'Abdu'l-Bahá's travels in both Europe and North America, he told the Bahá'ís on several 
occasions to put their religious beliefs in harmony with science and reason ('Abdu'l-Bahá, Paris Talks 146; Promulgation 107, 455). In Paris, he told his audience to "weigh carefully in the balance of reason and science everything that is presented to you as religion. If it passes this test, then accept it, for it is truth! If, however, it does not so conform, then reject it, for it is ignorance!"'(Paris Talks 144).

Certainly, the interpretations we make from religious writings should also be weighed 'in the balance of reason and science" and adjusted accordingly. Nevertheless, before we proceed further, we need to recognize two types of literalism, one religious and the other scientific, that must be avoided if we are to make meaningful interpretations. On the one hand, religious literalism piously regards every word of a sacred text or creed to be absolutely literal and thus rejects any theory, science, or branch of knowledge that seems to contradict its views. The problems with this approach have been discussed above. On the other hand, scientific literalism naively assumes a literal interpretation of religious writings and traditions, and rejects anything that does not conform to reason, scientific analysis, or the modern empirical understanding of the known physical universe. Both types of literalism are incorrect as both result from a misunderstanding of the nature and function of religious language. Hence, we should not make the common mistake of discarding every religious statement or concept that does not immediately stand in conformity with science and reason. When such apparent contradictions arise, we should first ask ourselves two questions: is the contradiction the result of our own limited understanding? and does it result from the nature and purpose of the veiled and symbolic language previously discussed? In fact, most, if not all, of these apparent contradictions are "tip-offs" or powerful warnings that we are dealing with the deliberate use of symbolism and mythological or sacred narrative which must be interpreted instead of discarded. Therefore, by first understanding a religious statement or ritual in the literal sense and then subjecting this understanding to the "balance of science and reason," we should be able to determine whether the intended meaning is primarily literal or symbolic. If the literal understanding is found to be in harmony with reason and established scientific knowledge, then we may assume that its primary meaning is literal, or at the very least, that a literal meaning is one of the possible meanings. If, however, the literal understanding is not reasonable and/or contradicts scientific knowledge, then we may have discovered the deliberate use of the veiled and symbolic language, which according to the Baháí writings, must not be interpreted literally (Bahá'u'lláh, The Kitáb-i-Íqán 254-55). Describing this process of recognizing the symbolic meaning through the literal one, the French philosopher Paul Ricoeur has written:

It is the recognition of the literal meaning that allows us to see that a symbol still contains more meaning. This surplus of meaning is the residue of thc literal interpretation. Yet for one who participates in the symbolic signification there are really not two significations, one literal and the other symbolic, but rather a single movement, which transfers him from one level to the other and which assimilates him to the second signification by means of, or through, the literal one. (Interpretation Theory 55)

Thus, by using the interpretive principles discussed so far, we can make interpretations that are reasonable and in accord with reason and the scientific understanding of the world, even though the literal sense of the text or tradition may not be!

\section{The Progressive and Relative Nature of Religious Truth}

A fundamental principle of the Bahá' Faith is that 'religious truth is not absolute but relative" and not static but dynamic and that the process of "Divine Revelation is progressive, not final." ${ }^{13}$ Should not our own interpretations of religious texts and traditions also be characterized by these same qualities? Yet, often a particular school of interpretation has come to dominate and even typify a particular culture, historical period, or religious tradition. If we are to avoid at least some of the mistakes of past religious traditions, we cannot restrict ourselves to only one or even several styles of interpretation; we must consider all interpretive methods in our search for meaning.

48

ture, and stage of human development in which it appears (Bahá'u'lláh, Gleanings 81; 'Abdu'l-Bahá, Some Answered Questions 48). Religious texts and beliefs are constrained to a certain worldview and cosmology, and are clothed in the language of a particular era and culture by the idioms, mannerisms, conventions, and topical references of the day. For example, in a letter addressed to an individual Bahá'í, Shoghi Effendi wrote: 'It is certainly most difficult to thoroughly grasp all the Surihs [chapters] of the Qur'an, as it requires a detailed knowledge of the social, religious, and historical background of Arabia at the time of the Prophet [Muhammad]" (qtd. in Lights 373).

Conscious neglect of these historical and cultural contexts may give rise to unwarranted and improbable interpretations that are anachronistic, absurdly literal, or extremely allegorical. For instance, such neglect is typical of the predominantly allegorical interpretations of the Bible made by the "Alexan drian School" of Christianity or those made by the Gnostics during the second and third centuries C.E. (Grant and Tracy, Short 
History 52-62). Thus, as we interpret, we must be conscious of the progressive and relative nature of religious truth, and in addition, we must not overlook or ignore the cultural and historical context inherent within religious writings, beliefs, and rituals.

\section{The Twofold Nature of Religion}

Closely related to the fourth principle of interpretation is the Baháí concept of the twofold nature of religion. The Bahá'í writings recognize two basic and fundamental aspects as characteristic of every religious tradition: one is "essen tial," the other "honessential." ${ }^{14}$ The essential aspect is common to all religious traditions and, according to the Bahá'́ writings, consists of human vir tues, ethical teachings, existential truths of life, and the awakening of human potential. The nonessential aspect operates within the sphere of cultural and historical circumstances, and primarily consists of social laws and regulations governing human affairs and interpersonal relationships. For example, most if not all religious traditions place great importance on the institution of marriage and the role of the family, but they all differ on the particulars of the marriage ceremony; the rights and obligations of the husband, wife, and children; and the circumstances under which divorce is granted. In addition, the American philosopher of religion John Hick cites a compelling example of this twofold aspect of religion:

When we look at the religious life of humanity, including Christianity as part of it, it is very natural to adopt the following position: religion is basically concerned with radical change in human beings from self-centeredness to Reality-centeredness (or in theistic terms, God-centeredness) - a transfor mation which is variously called salvation, enlightenment, liberation; and each of the world religions evidently constitutes an historical context within which this transformation occurs-and indeed occurs, so far as human observation can tell, to about the same extent. ${ }^{15}$

The distinction between the essential and nonessential aspects of religion is not unique to Bahá' theology. For instance, a similar idea is found in the theory of the German scholar Adolf Bastian (1826-1905). He made the distinction between what he termed the "elementary ideas" ( Elementargedanke) of humankind and the "ethnic ideas" (Volkergedanke) for the differently articulated local manifestations of the elementary or universal ideas. ${ }^{16}$

Our interpretations should take this twofold aspect of religious ideas into account. On the one hand, we should not unduly criticize a past religious law or custom that was appropriate for its time but that now appears to be in conflict with our modern view of the universe or our own cultural and religious background and presuppositions. On the other hand, while not ignoring the rich diversity of the various religious traditions, we should strive to recognize the essential elements common to most if not all traditions and not be sidetracked by nonessential differences in emphasis, terminology, or historical setting.

\section{The Problem of Personal Biases and Presuppositions}

The sixth principle of interpretation is concerned with the presuppositions, biases, and hidden agendas that we all bring to religious texts or traditions, especially unfamiliar or ancient ones. Throughout the Bahá'í writings, we are admonished not to judge religious writings by our own deficient standards. For instance, addressing the leaders of religion, Baháu'lláh warns:

Weigh not the Book of God with such standards and sciences as are current amongst you, for the Book itself is the unerring balance established amongst men. In this most perfect balance whatsoever the peoples and kindreds of the earth possess must be weighed, while the measure of its weight should be tested according to its own standard, did ye but know it. ${ }^{17}$

Elsewhere, we are asked to detach ourselves from human limitations and to purify our minds from vain imaginings, obscure thoughts, and the idle sayings of men (Bahá'u'lláh, The Kitáb-i-Íqán 3-4, 47, 192-93; Tablets 48). These and other human limitations can dramatically restrict our ability to perceive or "hear" the complete message of the text, with all its varied meanings, and thus, our understanding is correspondingly restricted and our interpretations skewed. However, no matter how much we try, we can never approach a religious text entirely free from presuppositions and human limitations. Nonetheless, we can become aware, at least partially, of our own biases and consciously use this awareness to minimize and limit their harmful influence.

Given that it is often easier to identify another person's biases, individuals may wish to incorporate consultation into the interpretive process. By consulting with peers, one increases the likelihood that personal biases will be identified and their impact on the interpretive process will be uncovered. In addition, the unique perspectives of each consultation participant would probably enrich the adequacy of the "Interpretive yield." 
The seventh interpretive principle is closely related to the sixth and involves the independent investigation of truth-a basic Baháí tenet ('Abdu'l-Bahá, Selections 298; Promulgation 433). This principle involves two interrelated aspects, both of which are crucial to the appropriate understanding of religious texts and beliefs. The first involves the renunciation of all forms of prejudice, superstition, and dogmatic thinking in our search for truth. 'Abdu'l-Bahá addressed this subject in 1912 during his stay in Paris:

...it is imperative that we should renounce our own particular prejudices and superstitions if we earnestly desire to seek the truth. Unless we make a distinction in our minds between dogma, superstition and prejudice on the one hand, and truth on the other, we cannot succeed. ${ }^{18}$

Although the general application of this teaching is obvious to almost everyone, how often do we let superstition, dogma (whether religious or scientific), and especially prejudice, interfere with and taint our understanding of the various religious traditions, particularly ancient or unfamiliar ones?

The second aspect of the independent investigation of truth is concerned with the human tendency to follow blindly or imitate others. In the Bahá'í writings, we are encouraged to search for truth independently from the opinions offered by either friends, family members, scholars, scientists, or religious and political leaders, no matter how powerful or well educated they may be. For example, during his travels in America, 'Abdu'l-Bahá told his audience in Malden, Mas sachusetts that

God has not intended man to imitate blindly his fathers and ancestors.... He must not be an imitator or blind follower of any soul. He must not rely implicitly upon the opinion of any man without investigation; nay, each soul must seek intelligently and independently, arriving at a real conclusion and bound only by that reality. ${ }^{19}$

In other words, we should develop receptive minds that are guided by our own thoughts and judgments and are as free as humanly possible from superstition, dogma, and prejudice. We should approach and interpret religious statements with the same spirit of receptivity and independence. Furthermore, the same approach should be taken when listening to the views and interpretations of others-whether Baháí or not. Commenting on this subject, the Universal House of Justice wrote the following advice to an individual believer: "The friends must therefore learn to listen to the views of others without being over-awed or allowing their faith to be shaken, and to express their own views without pressing them on their fellow Bahá'ís"( Wellspring 89),

\section{Interpretive Moderation}

The eighth and final interpretive principle involves the practice of moderation. I have saved the principle of moderation until last because it is so often neglected, and yet it is so vital to the balanced and appropriate use of the hermeneutical principles that we have discussed so far. In the Bahá'í writings we are told that whatsoever is carried to excess "will cease to exert a beneficial influence" and "will prove a source of evil," and thus, we are warned not to overstep the bounds of moderation (Bahá'u'lláh, Tablets 169, 69; Gleanings 235). Moreover, the writings of Bahá'u'lláh strongly encourage moderation in all things, including human utterance (Gleanings 342-43; Tablets 143, 199), The process of interpretation is not exempt from this principle. However, the historical record is filled with numerous and varied examples of excessive and outrageous approaches to the understanding of religious writings, doctrines, and rituals-often at the cost of untold human suffering, Unless we approach the process of interpretation from a moderate point of view, any one of the hermeneutical principles we have examined could be used in an extreme fashion. Are we willing to let history repeat itself through our immoderate actions? If not, we must learn to moderate all such tendencies toward exclusive methods or extreme forms of interpretation.

\section{Bahá'í Exegesis}

Richard Palmer defines the term exegesis as the actual commentary of a literary work in contrast to the principles, methods, or theories which make up the study of hermeneutics (Hermeneutics 34). Exegetical writings not only make up a substantial portion of the Bahá'í canon but also play a prominent role in shaping its theology. I would like to examine an example of Bahá'í exegesis in order to illuminate the process of interpretation and the interaction of some of the hermeneutical principles previously discussed. The example I have chosen is a metaphorical interpretation of the following prophetic passage from the Book of Isaiah:

The wolf shall dwell with the lamb, and the leopard shall lie down with the kid, and the calf and the lion and the fatling together, and a little child shall lead them. The cow and the bear shall feed; their young shall lie down together; and the lion shall eat straw like the ox. The suckling child shall play over the hole of the asp, and the weaned child shall put his hand on the adder's den. They shall not hurt or destroy in all my holy mountain; for the earth shall be full of the knowledge of the Lord as the 
waters cover the sea. (Isaiah 11:6-9, Revised Standard Version, cf. Isaiah 65:25)

Three steps are taken in the Bahá'í interpretation of this passage. The first step involves the use of reason and scientific knowledge to question the literal meaning. "There will never be a day when this prophecy will come to pass literally," explains "Abdu'l-Bahá, "for these animals by their natures cannot mingle and associate in kindness and love" (Promulgation 370). After pointing out the ignorance and folly of those who expect a literal fulfillment of this passage, Bahá'u'lláh rhetorically asks, 'Besides, of what profit would it be to the world were such a thing to take place?" (The Kitáb-i-Íqán 113). Thus, the absurdity of the literal understanding indicates that the primary meaning of this passage is symbolic.

The second step involves a symbolic interpretation. 'Abdu'l-Bahá states that these various animalsprey and predator, herbivore and carnivore-symbolize the "various nations, peoples, antagonistic sects and hostile races, who are as opposite and inimical as the wolf and lamb" (Some Answered Questions 63). That these same animals would lie down together and feed with each other symbolizes "the unity and agreement of races, nations and peoples who will come together in attitudes of intelligence, illumination and spirituality." ${ }^{, 20}$ Such events occur during the formative age of every religion when the divergent beliefs, hostile tribes, and antagonistic countries become unified under one common faith. The early histories of Islam and Christianity are good examples of this unifying effect.

The third and final step entails a "Bahá'í-centric" interpretation. ${ }^{21}$ "Abdu'l-Bahá asserts that this passage from Isaiah was fulfilled by Christ, while Baháu'lláh states that it was also fulfilled by Muhammad (Promulgation 200; Some Answered Questions 62-63; The Kitáb-i-Íqán 112-13). However, 'Abdu'l-Bahá points out that various antagonistic nations, peoples, and doctrines exist today. He, therefore, concludes that Christ only partially fulfilled this passage, whereas 'these verses apply word for word to Baháu'lláh" ( Some Answered Questions 63). The Bahá'í writings give a number of reasons for this conclusion: the cornerstone of all the Bahá'i teachings is the oneness of mankind; people from all races, nationalities, ethnic groups, and religious backgrounds are Bahá'ís; and the world is now at a stage in its development where the unification of all its peoples is for the first time possible (Shoghi Effendi, World Order 36, 42-43; 'Abdu'l-Bahá, Promulgation 370).

Although this interpretation is made by Bahá'u'lláh and 'Abdu'l-Bahá, I feel that it serves as a model for our own interpretations. In closing, we should note that both Bahá'u'lláh and 'Abdu'l-Bahá do not reject or question the authenticity of Isaiah 11:6-9 merely on the basis that the literal understanding does not conform with reason or scientific observations of the predator-prey relationship. Instead, both reject the literal sense of the passage and render a reasonable and profoundly meaningful interpretation that honors the dynamics and mythological nature of religious language.

\section{Conclusion}

A number of important conclusions can be drawn from our preliminary examination of the eight hermeneutical principles found within the Bahá'í writings. First, while these may not be the only interpretive principles found within the Bahá'í writings, they certainly constitute some of the most important ones. Second, individual interpretation is repeatedly encouraged within the Baháí writings and is recognized as being crucial to our understanding of the various religious traditions. Third, we must interpret not only religious texts and sacred writings but also the beliefs, doctrines, rituals, and ceremonies which are derived from these texts (or which precede the text in the case of illiterate tribal societies). Fourth, the eight principles of interpretation that we have examined function interdependently and in concert with each other. Therefore, we should develop an integrated and balanced approach to interpretation, avoiding the extreme or excessive use of anyone principle over the others. Fifth, since religious writings contain a variety of meanings, we should consider all interpretations warranted by the text. And most important, religious language primarily communicates a vision or interpretation of life, in contrast to philosophical, historical, scientific, or textbook accounts of the world. This vision of life is often clothed in symbolic language and embedded in mythological narratives that must be reinterpreted in every age. 


\section{Notes}

1. Palmer (Hermeneutics 3-4) briefly discusses the importance of hermeneutics to the fields of theology, philosophy, and literary interpretation. Psychiatrist Steven T. Levy, in his book Principles of Interpretation, examines the role of interpretive principles in psychoanalytic psychotherapy. He begins the final chapter (Chapter 9: "General Principles of Interpretation") by asserting that "the interpretive process is the central therapeutic activity of the therapist."

2. The term canon is usually defined as a list of religious writings which are officially approved or recognized as authoritative and/or divinely inspired. Given this definition, the Bahá'í canon would include the writings of the Báb, Baháu'lláh, 'Abdu'l-Bahá, Shoghi Effendi, and the Uni versal of House of Justice. It would not include the recorded utterances of the above nor would it include pilgrims' notes, as Shoghi Effendi clearly points out: "Nothing can be considered scripture for which we do not have an original text" ( Unfolding Destiny 208).

3. Translated from the Greek word thlipsis, which literally means pressure. Bahá'u'lláh examines the symbolic meaning of this word within the larger context of interpreting the prophetic twenty-fourth chapter of Matthew.

4. From a letter written by the Universal House of Justice to an individual believer, dated 27 May 1966. In Wellspring of Guidance 89. See also the letter dated 25 April 1926 written on behalf of Shoghi Effendi to an individual believer, in The Importance of Deepening our Knowledge and Understanding of the Faith: Excerpts from the Writings of Bahá'u'lláh, 'Abdu'l-Bahá and Shoghi Effendi 29.

5. The Kitáb-i-Íqán: The Book of Certitude 255, 49. This twofold language is symbolized in both the Bible and Bahá'í writings as a sword, especially a two-edged sword. See Hebrews 4: 12, Ephesians 6:17, Revelation 1:6, 2:16, 19:15, Matthew 10:34-35, Isaiah 49:2, The Kitáb-i-Íqán 111-12, and Promulgation of Universal Peace 199, 292.

6. 'Abdu'l-Bahá, The Promulgation of Universal Peace 246. See also ‘Abdu'l-Bahá, Some Answered Questions 100.

7. A brief listing of some of these symbolic terms would include the following: life, death, graves, tombs, resurrection of the dead, the judgement day, earth, heaven, hell, fire, Satan, evil spirits, angels, bread, clouds, smoke, darkness, sun, moon, stars, trumpet, reborn, fruits, the tree of life, blindness, sleep, wild beasts, earthquakes, famines, mountains, and the new Jerusalem.

8. Examples of religious myths that are interpreted symbolically include the following: the creation of the world, birth stories, Adam and Eve in the Garden of Eden, Exodus and the crossing of the Red Sea, Noah's Ark and the Flood, Jonah and the whale, and descriptions of heaven and hell, God and other divine beings, the human soul, miraculous healings, and possession by evil spirits. Examples of religious doctrines that are interpreted symbolically include: reincarnation, baptism, the trinity, and the resurrection and second corning of Christ.

9. T. Patrick Burke, The Reluctant Vision: An Essay in the Philosophy of Religion 37. For a good discussion on the role and function of religious language, see chapters 1 and 2.

10. The Secret of Divine Civilization 98-99 and "Abdu'l-Bahá in London" 78, in The Importance of Deepening our Knowledge and Understanding of the Faith: Extracts from the Writings of Bahá'u'lláh, 'Abdu'l-Bahá and Shoghi Effendi 18.

11. William Righter, Myth and Literature 94, quoted in Doty, Mythography 16.

12. Comments by the Research Department of the Universal House of Justice on the report of the Bahá'i Studies Seminar on Ethics and Methodology held in Cambridge, England, Sept. 30-Oct.1, 1978. Also published in Bahá'í News, June 1979 and most recently quoted in The Journal of Bahá'í Studies, 1.1(1988):33.

13. Shoghi Effendi, The World Order of Bahá'u'lláh: Selected Letters from Shoghi Effendi 58. Shoghi Effendi also writes (in Guidance for Today and Tomorrow 118, 133) that Baháu'ulláh actually disclaimed the finality of his own Revelation.

14. 'Abdu'l-Bahá, Promulgation of Universal Peace 168-69, 364-65, 393; Some Answered Questions 48; and Baháu'lláh, Gleanings from the Writings of Bahá'u'lláh 287-88.

15. John Hick, Abstracts 71. See also John Hick and Paul F. Knitter, eds. The Myth of Christian Uniqueness: Towards a Pluralistic Theology of Religions 23.

16. Joseph Campbell, The Masks of God: Primitive Mythology 32. Campbell points out that Carl Jung's idea of the "archetypes" was developed from the theory of Bastian.

17. Baháu'lláh, Synopsis and Codification of the Laws and Ordinances of the Kitáb-i-Aqdas 22. See also Baháu'lláh, The Kitáb-i-Íqán 47, 70 and Nabíl-i-A 'zam, The Dawn-Breakers: Nabíl's Narrative of the Early Days of the Bahá'i Revelation 61,318-19.

18. 'Abdu'l-Bahá, Paris Talks 136. See also Baháu'lláh, "The Tablet of the True Seeker," The Kitáb-i-Íqán $192-95$.

19. 'Abdu'l-Bahá, Promulgation of Universal Peace 291, 293-94; See also Baháu'lláh, The Seven Valleys and the Four Valleys 5 and the Báb, Selections from the Writings of the Báb 90-91.

20. 'Abdu'l-Bahá, Promulgation of Universal Peace 370. Baháu'lláh makes a similar inter pretation in The 
Kitáb-i-Íqán, 111-13. According to William E. Bierderwolf, various Christian writers have made similar interpretations-most notably, Martin Luther, John Calvin, and the early church fathers (The Second Coming Bible 58-60). Similar interpretations are also found in Matthew Henry's Commentary on the Whole Bible (74$75)$ and in The Interpreter's Bible, vol. 5 (249-50).

21. A 'Bahá'í-centric" interpretation derives from a uniquely Baháí understanding of past religious traditions. It finds Bahá'í principles and the central figures of the Bahá'í Faith prefigured or "pretypified" in other

religious scriptures. I borrow this concept from the Christocentric exegesis of Paul and other early Christian writers as described by Grant and Tracy in A Short History of the Interpretation of the Bible 20-27.

\section{Works Cited}

‘Abdu'l-Bahá. Paris Talks. Trans. Sara Blomfield et al. 11th ed. London: Baháí Publishing Trust, 1969.

- The Promulgation of Universal Peace: Talks Delivered by 'Abdu'l-Bahá during His Visit to the United States and Canada in 1912. Comp. Howard MacNutt. 2d ed. Wilmette: Bahá'í Publishing Trust, 1982.

- The Secret of Divine Civilization. Trans. Marzieh Gail with 'Alí-Kuli Khan. 3d ed. Wilmette: Baháí Publishing Trust, 1975.

- Selections from the Writings of 'Abdu'l-Bahá. Comp. Research Department. Haifa: Baháí World Cen tre, 1978.

- Some Answered Questions. Comp. and trans. Laura Clifford Barney. Wilmette: Baháí Publishing Trust, 1981.

The Báb. Selections from the Writings of the Báb. Comp. Research Department. Haifa: Baháí World Centre, 1976.

Bahá'u’lláh. Gleanings from the Writings of Baháu’lláh. Trans. Shoghi Effendi. Wilmette: Baháí Publishing Trust, 1976.

— The Kitáb-i-Íqán: The Book of Certitude. Trans. Shoghi Effendi. Wilmette: Bahá’í Publishing Trust, 1950.

- The Seven Valleys and the Four Valleys. Trans. Marzieh Gail with 'Alí-Kuli Khan. Wilmette: Bahá'í Publishing Trust, 1975.

- A Synopsis and Codification of the Kitáb-i-Aqdas: The Most Holy Book of Bahá'u'lláh. Haifa: Bahá’í World Centre, 1973.

- Tablets of Baháu'lláh Revealed after the Kitáb-i-Aqdas . Comp. Research Department. Haifa: Bahá'í World Centre, 1978.

Baháu’lláh and 'Abdu'l-Bahá. Baháỉ World Faith. Wilmette: Bahá'í Publish ing Trust, 1956.

Beiderwolf, William E. The Second Coming Bible. Grand Rapids: Baker Book House, 1980.

Brown, Robert McAfee. Theology in a New Key: Responding to Liberation Themes. Philadelphia: Westminster Press, 1978.

Bultmann, Rudolf K. Jesus Christ and Mythology. New York: Scribner, 1958.

Burke, Thomas Patrick. The Reluctant Vision: An Essay in the Philosophy of Religion. Philadelphia: Fortress Press, 1974.

Campbell, Joseph. The Masks of God: Primitive Mythology. New York: Penguin Books, 1969. 
Doty, William G. Mythography: The Study of Myths and Rituals. The University of Alabama Press, 1986.

Grant, Robert M. and David Tracy. A Short History of the Interpretation of the Bible. 2d ed. Philadelphia: Fortress Press, 1984.

Henry, Matthew. Matthew Henry's Commentary on the Whole Bible. 1712; rpt. New York: Fleming H. Revell, n.d.

Hick, John. Abstracts: AARISBL Annual Meeting. Baltimore: Scholars Press, 1987.

Hick, John, and Paul F. Knitter, eds. The Myth of Christian Uniqueness: Towards a Pluralistic Theology of Religions. Faith Meets Faith Series. Maryknoll: Orbis Books, 1987.

Holy Bible: Revised Standard Version, The. 2d ed. Nashville: Thomas Nelson, 1971.

Importance of Deepening our Knowledge and Understanding of the Faith: Extracts from the Writings of Bahá'u'lláh, 'Abdu'l-Bahá, and Shoghi Effendi, The . Comp. Research Department. Haifa: Bahá'í World Centre, 1983.

Interpreter's Bible, The. Vol. 5. New York: Abingdon Press, 1956.

Levy, Steven. Principles of Interpretation. Northvale: Jason Aronson, 1984.

Lights of Guidance : A Bahá ’́ Reference File. Comp. Helen Hornby. New Delhi: Baháí Publishing Trust, 1983.

Nabíl-i-A 'zam (Muhammad-i-Zarandí). The Dawn-Breakers: Nabíl's Narrative of the Early Days of the Bahá’ Revelation. Trans. and ed. Shoghi Effendi. Wilmette: Baháí Publishing Trust, 1974.

Palmer, Richard. 'Hermeneutics: Interpretation Theory" in Schleiemwcher, Dil they, Heidegger, and Gadamer. Studies in Phenomenology and Existential Philosophy. Evanston: Northwestern University Press, 1969.

Ricoeur, Paul. Interpretation Theory: Discourse and the Surplus of Meaning. Ft. Worth: Texas Christian University Press, 1976.

Shoghi Effendi. Guidance for Today and Tomorrow: A Selection from the Writings of Shoghi Effendi. London: Bahá'í Publishing Trust, 1953.

- The Unfolding Destiny of the British Bahá'i Community: The Messages from the Guardian of the Bahá'í

Faith to the Bahá'is of the British Isles. London: Bahá'́ Publishing Trust, 1981.

- The World Order of Bahá'u'lláh: Selected Letters from Shoghi Effendi . 2nd ed. Wilmette: Bahá'í Publishing Trust, 1974.

Tillich, Paul. Dynamics of Faith. New York: Harper and Row, 1957.

Universal House of Justice. Wellspring of Guidance: Messages 1963-1986. Rev. ed. Wilmette: Bahá'í Publishing Trust, 1976. 